\title{
Analysis of the Individual Travel Insurance in the Czech Republic
}

\author{
Zdeněk Rybák*
}

\begin{abstract}
:
The main goal of this paper is to provide the description, current offer and factors behind the premia differences of the travel insurance products offered in the Czech Republic. It focuses on the premia pricing, risks covered, claim limits, product distribution and terms and conditions in comparison with the Central European region. Also, there are expressed findings, limitations and trends of this product. The paper first analyses the whole market of travel insurance. Next, it focuses on the travel insurance in general in order to provide the readers with some basic information. There is provided a description of the situation in the Czech Republic, such as the travel insurance with details on the risks covered, forms of the travel insurance, distribution channels, limits for the coverage, price factors (age, purpose of the trip, destination, length of the trip). The analysis is complemented by price analysis in order to provide the price factor overview to this product, with an expansion and comparison of prices within the Central European region. The final part of the paper discusses findings on the travel insurance and also provides current trends in the travel insurance industry of the Czech Republic.
\end{abstract}

Key words: Travel insurance; Insurance; Risks; Czech Republic.

JEL classification: G20, G22, I13.

\section{Introduction}

The current trend of travelling offers many opportunities for travellers to visit any country in the world. Many people travel into different countries on a daily basis. Travelling, however, also entails risks that "anything unexpected may happen and can cause a negative impact on our life". As a reaction, insurance products provide coverage to these travellers who travel abroad.

The travel insurance is a kind of non-life insurance which provides coverage of risks that happen abroad (Ducháčková, 2009; Ducháčková, Daňhel, 2012). The importance and relevancy of arranging the travel insurance while travelling is undisputable (Andreeva, 2016; Sharkey, 2017) as it protects the clients from potential extreme costs in the order of millions of CZK for medical care provided abroad (Allianz, 2012; Slavia insurance company, 2017) in exchange for a

\footnotetext{
Zdeněk Rybák; University of Economics, Prague, Faculty of Finance and Accounting, Department of Corporate Finance, W. Churchill Sq. 4, 13067 Prague 3, Czech Republic, <xrybz03@vse.cz>.

The article is processed as an output of the research project under IGA project IGS F1/21/2016

"Vývojové trendy v bankovnictví a pojišt'ovnictví v podmínkách měnících se finančních trhů".
} 
relatively small price of the insurance premium (in the magnitude of tens of CZK per day, more on that further in the text).

The main goal of this paper is to provide the description, current offer and factors behind the premia differences of the travel insurance products offered in the Czech Republic with a focus on the detail of premia pricing, risks covered, claim limits, products' distributions and the terms and conditions. Another goal is to describe findings, limitations and trends of this product. In order to meet the paper's goals, the article expands the review of short-term premia, claim limits and trend overview of the travel insurance in the Central European region.

\section{Data and Methodology}

The paper focuses on the commercial short-term travel insurance for individuals arranged by Czech insurance companies and it abstracts from insurance of foreigners, classified as a different insurance category. The market analysis is based on the market and/or insurance companies' data covering the period 2011 2018.

Premia pricing and claim limits are analysed based on the defined model example in the Czech Republic and in the Central European region according to the online available calculators of selected insurance companies or intermediaries. Terms and conditions or other details are based on the individual products' documentations. Some specifics of the travel insurance market are based on direct surveys of travel insurance companies or assistant services.

Premia prices on the market are extremely diverse. Nevertheless, for the purpose of this paper we focus on the minimum possible premia prices, model defined risks included in the travel insurance and maximum claim limits.

\section{Travel Insurance Market in the Czech Republic}

In the Czech Republic, there operate 51 registered insurance companies. ${ }^{1}$ About 20 insurance companies offer travel insurance products. The main reason behind the number of insurers is that the travel insurance seems to be a profitable product. This can be supported by Table 1, showing the revenue and claim ratio of the travel insurance in the Czech Republic.

As of 23 May 2017; Source: The Czech National Bank; lists of the regulated institutions and registered financial market entities. 
Tab. 1 Travel insurance revenue and claim ratio in the Czech Republic (in CZK thousand)

\begin{tabular}{lcrrrr}
\hline Year & $\mathbf{2 0 1 5}$ & $\mathbf{2 0 1 4}$ & $\mathbf{2 0 1 3}$ & $\mathbf{2 0 1 2}$ & $\mathbf{2 0 1 1}$ \\
\hline $\begin{array}{l}\text { Written premia by the travel } \\
\text { insurance }\end{array}$ & $1,920,821$ & $1,985,797$ & $1,921,928$ & $1,979,860$ & $1,962,250$ \\
$\begin{array}{l}\text { Claims paid by the travel } \\
\text { insurance }\end{array}$ & 683,019 & 654,934 & 611,093 & 629,069 & 695,123 \\
$\begin{array}{l}\text { Claims ratio of the travel } \\
\text { insurance (in \%) }\end{array}$ & 36 & 33 & 32 & 32 & 35 \\
\hline
\end{tabular}

Source: Annual reports - The Czech Insurance Association, authorial computation.

Table 1 shows that the travel insurance market gained over $60 \%$ in written premia reported over the last five years which were not used for claim payments. These figures can be supplemented by claim ratios of the selected insurance companies detailed in Table 2.

Tab. 2 Claims ratio of selected insurance companies (in \%)

\begin{tabular}{|c|c|c|c|c|c|}
\hline Year & 2015 & 2014 & 2013 & 2012 & 2011 \\
\hline Kooperativa & 31 & 30 & 31 & 25 & 32 \\
\hline Uniqa & 35 & 34 & 38 & 32 & 32 \\
\hline Komerční insurance company & 18 & 24 & 15 & 35 & - \\
\hline
\end{tabular}

Source: Annual reports of the selected insurance companies, authorial computation.

According to the results, it is possible to state that prices of insurance products are set correctly with a profit outlook. There could be potential for a new insurance company with new travel insurance products based on lower premia to enter the market of the Czech Republic. Figures above could be supplemented by a comparison with the whole market or the non-life insurance market.

Tab. 3 Claims ratio of the insurance market (whole, non-life) in the Czech Republic (in CZK thousand)

\begin{tabular}{lrrrrr}
\hline Year & \multicolumn{1}{c}{$\mathbf{2 0 1 5}$} & $\mathbf{2 0 1 4}$ & $\mathbf{2 0 1 3}$ & $\mathbf{2 0 1 2}$ & $\mathbf{2 0 1 1}$ \\
\hline $\begin{array}{l}\text { Written market } \\
\text { premia }\end{array}$ & $116,461,520$ & $115,399,026$ & $114,329,456$ & $115,615,585$ & $115,627,683$ \\
Market claims paid & $92,265,421$ & $98,047,262$ & $95,220,973$ & $84,242,627$ & $82,455,222$ \\
$\begin{array}{l}\text { Claims ratio market } \\
\text { (in \%) }\end{array}$ & 79 & 85 & 83 & 73 & 71 \\
$\begin{array}{l}\text { Non-life written } \\
\text { premia }\end{array}$ & $71,908,280$ & $69,197,628$ & $67,839,583$ & $68,172,347$ & $69,052,154$ \\
$\begin{array}{l}\text { Non-life claims paid } \\
\text { Claims ratio non-life }\end{array}$ & $44,432,901$ & $44,218,904$ & $47,857,938$ & $41,489,836$ & $43,660,309$ \\
insurance (in \%) & 62 & 64 & 71 & 61 & 63 \\
\hline
\end{tabular}

Source: Annual reports - The Czech Insurance Association, authorial computation. 
Table 3 shows that the claim ratio of the whole Czech insurance market was at least $71 \%$ during the reference period. The claims ratio of the non-life insurance was at least $61 \%$. Compared to the results of the travel insurance claim ratios at slightly above $30 \%$, the travel insurance is a profitable product.

\section{Travel Insurance}

According to the Council Regulation (EEC) 1408/71 and 574/72, any insured citizen of the EU Member State is on the territory of another Member State entitled to medically necessary health care, taking into account the nature of the disease and the expected length of stay. There are over ten million people ${ }^{2}$ insured in the Czech Republic, meaning that according to this regulation, most people in the Czech Republic should be insured for the main risks that may happen to them within the European Union.

However, among the health care systems of the European Union there are many differences that cause diverse payments for the clients' care. Participation on the health care and other extra costs vary across countries, so this could be covered by the commercial travel insurance for individuals. When travelling outside the EU, it is essential to arrange the travel insurance, as medical expenses could be extremely high (e.g. the further away from the EU border, the higher the costs for repatriation).

The travel insurance is a product offered by insurance companies with a general purpose to cover realization of defined risks that happened abroad. The main purpose of the travel insurance is to cover not only the client's life (medical expenses) as in the case of the European insurance card, but to cover also the property, liability (Hun Seog, 2010) and other risks that happen abroad. Travel insurance products are usually designed as a package of risks covered. Each package contains different risks covered and as a result, premia for the coverage vary.

\subsection{Premium price factors}

Within the analysis, there were found diverse pricing factors adopted for specifying the premia tariff groups (Cipra, 2006) by travel insurance companies. Important factors are: risks covered, terms and conditions specified (exclusions), form of insurance, distribution channels, limits for the coverage, destination of travelling, insurance period, purpose of the trip and current health condition and age of the person insured.

2 Exact number: 10,432,196 persons insured as of 1 January 2016, Source: Ministry of Health of the Czech Republic, read on the 31 October 2017. 
Some insurance companies provide an extra discount, e.g. for specific groups such as students or insurance for adults including a free coverage for their children. ${ }^{3}$ Also, there can be used coupons with a specific code, received by partners of the insurance company, which lower the premia. This coupon can be used at the website of the respective insurance company. There can exist any price discount, e.g. in the case a client has more financial products, the insurance company responds to this and provides a corresponding discount.

\section{Travel insurance risks covered and exclusions}

Travel insurance products have a large variety of risks covered. It is important to specify these risks, as they are important for the purpose of the trip. Travel insurance products are usually designed as a package of the coverage. In general, the travel insurance package contains a mix of risk covered, e.g. insurance of emergency medical expenses abroad. This includes costs coverage of medical treatment, dental treatment, hospitalization, drugs, transport and repatriation. On the other hand, the accident insurance covers such risks as accidental death, permanent consequences of an injury, daily compensation; additional assistance services; damage liability insurance; baggage insurance; legal protection insurance; cancellation fee insurance; unused vacation insurance; stopover insurance; veterinary insurance; insurance of abandoned home.

As oppose to the risks available to cover under insurance, there exist exclusions. Exclusions are parts of the terms and conditions and specify situations in which the claimed amount will not be paid by the insurance company. Exclusions differ with each insurance company and have a direct impact on the premia. They are a general part of the travel insurance product and specific for supplementary insurance.

Understanding of exclusions is important. The reason can be described as follows: in case the client would like to go skiing, some insurance companies define skiing as a risky sport in exclusions for basic sport coverage, so it is important to arrange a supplementary insurance for risky sports. On the other hand, some insurance companies keep skiing included in the basic coverage. Overall, it is important to double check whether the client has risks covered and whether these risks are not under exclusions.

\section{Forms of travel insurance}

The travel insurance can be divided into two different forms based on the insurance arrangement. The most common is the individual travel insurance,

As an example - Česká insurance company or Kooperativa, children under 6 years accompanied by an adult have a free travel insurance. 
which is sold on demand of a client and its definition is based on the clients' needs (risks covered, claim limits and services included in the travel insurance). The price of this product is individually calculated. Usually, this type of insurance can be arranged on the individual or group basis and can be concluded for a short period (few days) or for a longer period (usually renewed in one year).

- advantages: individuality (services, price)

- disadvantages: frequency of arrangement (each trip)

Another form of the travel insurance product is the associated travel insurance. The travel insurance (and/or covering risks that happened abroad) is associated with any service or product and its main goal is to provide the client with extra services. The most frequent application is providing the travel insurance by the credit or debit card's issuer or by the international student identity card. In this case, if the owner of the card travels abroad, s/he receives an automatic travel insurance coverage.

- advantages: low price, sometimes free of charge

- disadvantages: lower claim limits, less services included, sometimes regular monthly fee

Illustrations of selected prices for the basic associated travel insurance coverage by selected banks through debit cards are shown in Table 4. Details on the individual travel insurance are provided further in the text.

\section{Tab. 4 Additional premia for travel insurance coverage by debit cards (in CZK)}

\begin{tabular}{lrll}
\hline Institution & $\begin{array}{l}\text { Basic limit for } \\
\text { Medical expenses } \\
\text { coverage }\end{array}$ & Premium & $\begin{array}{l}\text { Specific } \\
\text { conditions }\end{array}$ \\
\hline Česká spořitelna & $1,500,000$ & $300 /$ annually & \\
Komerční banka & $1,000,000$ & free of charge & \\
ČSOB & $1,500,000$ & $500 /$ annually & \\
Mbank & $1,000,000$ & $420 /$ annually & \\
Fio banka & $2,000,000$ & $300 /$ annually & \\
ISIC (Uniqa) & $2,000,000$ & $200 /$ annually & owner of ISIC card \\
\hline
\end{tabular}

Source: Websites of selected banks.

Table 4 shows that main limits are lower for this form of the travel insurance than for the individually arranged form (as further described in Chapter 5). 
Nevertheless, fees are lower and quite competitive to the individually based insurance products. ${ }^{4}$

\section{Distribution channels of travel insurance}

Distribution of the travel insurance has a lot of varieties. It is possible to divide the distribution into:

- Direct - products are sold directly by the insurer. There is a large variety of channels and currently it is possible to arrange insurance via:

- office of the insurance company

- website of the insurance company

- smartphone/tablet PC application of the insurance company

- telephone call with the insurance company

- Intermediaries - distribution of the travel insurance via intermediaries who must be licensed by the Czech National Bank. An intermediary may be a person in the office or an institution which sells the insurance products "online". This channel can be useful for people with low financial literacy and can assist with selling the correct product and comparison of the market offer. In detail, the distribution can be via:

- office of the intermediary

- website of the intermediary

- smartphone/tablet PC application of the intermediary

- telephone call with the intermediary

- Included - this kind of distribution of insurance products is included in the product/service purchased, mostly automatically and free of charge. The travel insurance added as a service to the clients' debit/credit cards can be an example.

- Partnership - the most important distribution channel ${ }^{5}$ - selling insurance through travel agencies. Insurance company is an insurer, travel agency is a policyholder and each client of the given travel agency is insured, unless the client refuses, according to the framework agreement.

The travel insurance is one of the most selling products via alternative (electronic) channels ${ }^{6}$ due to its simplicity and standardization. The current trend is to use

4 It is important to be familiar with the risks covered, claim limits and terms and conditions with this kind of the travel insurance as these products are already limited. Also it is important to bring along the card.

5 Based on the survey of travel insurance companies.

6 It is available only a few insurance products via alternative (electronic) channels and the travel insurance is one of the most popular products, besides the vehicle (accident and liability) insurance. 
electronic distribution channels (websites and mobile applications) for travel insurance products due to the wide scale of discounts, technology development and simple arrangement. The process of selecting the product, filling necessary details for arrangement of the insurance, payment and providing necessary documentation to the client is fast, comfortable and time-saving. These channels are also convenient for insurance companies, because these do not have to pay fees to insurance intermediaries. Discounts on the premia are about $10 \%-20 \%$ for the electronic distribution channels when compared to the standard premia. Disadvantage of this distribution channel is a higher eligibility for financial literacy.

\section{Claim settlement process}

Critical part of the travel insurance is the claim settlement. The reason for this is that claims happen abroad and there can be language, financial or other barriers that cannot be easily resolved under the claim settlement process and this is why the claim settlement process is outsourced to specific assistance services.

The settlement process is mainly provided and driven by a specific company (e.g. AXA Assistance, Europ Assistance), which has a contract with the insurance company and provides assistant services. It is available 24/7 in Czech and can also support English and/or other foreign languages. Processing is via assistance and the insurer covers only amounts that are paid in case the claim occurs according to the travel insurance contract.

There are several methods for the claim settlement. Claims with a low claim amount are mostly paid by a client following his or her treatment directly to the medical service institution. The amount is claimed retrospectively from the insurance company or assistance service once the client returns home. Claims of higher amounts can be solved through prepayment by the assistance service or insurance company.

\section{Travel Insurance in the Czech Republic and the Central European Region}

There is a wide diversity in products offered by insurance companies in the Czech Republic and it is difficult to cover all the combinations offered. Because of this, there is provided only general information and in some parts, the focus aims on the situations based on the Czech market.

The selection is supplemented by the example of a travel insurance arrangement offered by selected insurance companies on behalf of a thirty years old person with the following assumptions: minimal price, tourist trip, period 17 June 2017 - 18 June 2017, two destinations - Europe (when possible, Austria) and the USA, basic risks to cover: medical expenses, accident insurance and liability insurance. Results of the price analysis are shown in Table 5. 
Tab. 5 Premium amount for the example coverage (as of May 2017, in CZK)

\begin{tabular}{|c|c|c|c|c|c|}
\hline \multirow[b]{2}{*}{$\begin{array}{l}\text { Insurance } \\
\text { company }\end{array}$} & \multirow{2}{*}{$\begin{array}{l}\text { Main limit } \\
\text { for } \\
\text { medical } \\
\text { expenses } \\
\text { coverage }\end{array}$} & \multicolumn{2}{|c|}{ Austria } & \multicolumn{2}{|c|}{ USA / world } \\
\hline & & $\begin{array}{l}\text { www.top- } \\
\text { pojisteni.cz }\end{array}$ & $\begin{array}{l}\text { Other } \\
\text { channels }\end{array}$ & $\begin{array}{l}\text { www.top- } \\
\text { pojisteni.cz }\end{array}$ & $\begin{array}{l}\text { Other } \\
\text { channels }\end{array}$ \\
\hline AIG/Colonnade & $5,000,000$ & 194 & $\begin{array}{l}\text { website: } \\
149\end{array}$ & 495 & website: 495 \\
\hline Allianz & unlimited & 190 & $\begin{array}{l}\text { website: } \\
194\end{array}$ & 630 & website: 630 \\
\hline AXA & $5,000,000$ & 40 & $\begin{array}{l}\text { website: } 84 \\
\text { / } 67\end{array}$ & 63 & $\begin{array}{l}\text { website: } 128 / \\
102\end{array}$ \\
\hline $\begin{array}{l}\text { Česká } \\
\text { insurance } \\
\text { company }\end{array}$ & $3,000,000$ & - & $\begin{array}{l}\text { website: } 80 \\
\text { / } 72 \text {; } \\
\text { android } \\
\text { app: } 72\end{array}$ & - & $\begin{array}{l}\text { website: } 124 \text { / } \\
\text { 111; android } \\
\text { app: } 111\end{array}$ \\
\hline С̆PP & $2,500,000$ & - & $\begin{array}{l}\text { website: } 63 \\
\text { / } 50\end{array}$ & - & $\begin{array}{l}\text { USA } \\
\text { impossible }\end{array}$ \\
\hline $\begin{array}{l}\text { ČSOB } \\
\text { insurance } \\
\text { company }\end{array}$ & $5,000,000$ & 42 & website: 61 & 70 & website: 103 \\
\hline Direct & unlimited & - & website: 90 & - & website: 135 \\
\hline ERGO & $5,000,000$ & 54 & website: 60 & 124 & website: 138 \\
\hline ERV & $3,000,000$ & 190 & $\begin{array}{l}\text { website: } \\
250\end{array}$ & 690 & website: 370 \\
\hline Generali & $3,000,000$ & 44 & website: 51 & 70 & website: 77 \\
\hline HVP & $3,000,000$ & - & - & - & - \\
\hline $\begin{array}{l}\text { Komerční } \\
\text { insurance } \\
\text { company }\end{array}$ & $3,000,000$ & - & $\begin{array}{l}\text { website } 108 \\
\text { / } 98 ; \\
\text { android } \\
\text { app: } 62 \text { / } 56\end{array}$ & - & $\begin{array}{l}\text { website } 108 \text { / } \\
\text { 98; android } \\
\text { app: } 100 \text { / } 90\end{array}$ \\
\hline Kooperativa & $5,000,000$ & - & $\begin{array}{l}\text { website: } 80 \\
/ 72\end{array}$ & - & $\begin{array}{l}\text { website: } 112 \text { / } \\
101\end{array}$ \\
\hline Maxima / Bupa & - & - & - & - & - \\
\hline Slavia & $3,500,000$ & 46 & $\begin{array}{l}\text { website: } 50 \\
\text { (coverage } \\
5000,000 \text { ) }\end{array}$ & 74 & $\begin{array}{l}\text { website: } 108 \\
\text { (coverage } \\
5000,000)\end{array}$ \\
\hline Uniqa & $5,000,000$ & 52 & $\begin{array}{l}\text { website: } 62 \\
\text { /56 }\end{array}$ & 98 & $\begin{array}{l}\text { website: } 108 \text { / } \\
97\end{array}$ \\
\hline Union & $2,500,000$ & 68 & $\begin{array}{l}\text { website: } 36 \\
\text { (unlimited } \\
\text { coverage) }\end{array}$ & 92 & $\begin{array}{l}\text { website: } 80 \\
\text { (unlimited } \\
\text { coverage) }\end{array}$ \\
\hline Vitalitas & $5,000,000$ & - & website: 74 & - & website: 162 \\
\hline
\end{tabular}


Rybák, Z.: Analysis of the Individual Travel Insurance in the Czech Republic.

\begin{tabular}{llllll}
\hline & $\begin{array}{l}\text { Main limit } \\
\text { for } \\
\text { Insurance } \\
\text { company }\end{array}$ & \multicolumn{2}{c}{ Austria } & \multicolumn{2}{c}{ USA / world } \\
\cline { 3 - 6 } & $\begin{array}{l}\text { medical } \\
\text { expenses }\end{array}$ & $\begin{array}{l}\text { www.top- } \\
\text { pojisteni.cz }\end{array}$ & $\begin{array}{l}\text { Other } \\
\text { channels }\end{array}$ & $\begin{array}{l}\text { www.top- } \\
\text { pojisteni.cz }\end{array}$ & $\begin{array}{l}\text { Other } \\
\text { channels }\end{array}$ \\
\hline VZP & $2,000,000$ & 40 & $\begin{array}{l}\text { website: } 36 \\
\text { (coverage } \\
3,000,000)\end{array}$ & 64 & $\begin{array}{l}\text { website: } 103 \\
\text { (coverage } \\
3,000,000)\end{array}$ \\
\hline
\end{tabular}

Source: Websites of the selected insurance companies and intermediaries.

Note: Premium without discount / with discount.

The most important part of insurance represents the coverage of medical expenses, standard limit of which (as high as possible by the travel insurance providing the model coverage) is described in the second column. Where possible, there were analysed prices by the insurance intermediary (www.top-pojisteni.cz) and also at direct websites / mobile applications of the insurance companies in order to cover most of the electronic distribution channels in the Czech Republic.

The results from analysis can be described as there are notable differences among insurance companies in terms of hundreds of per cent. For example, AIG (currently Colonnade) versus Union; AIG (currently Colonnade) has five times higher premium for the European region and six times higher for the world region than the price quoted by the Union insurance company, which has the lowest premium of all the reviewed insurance companies. The European region is cheaper than the world region. Premia by intermediaries are generally lower than by insurers. Android application premia are cheaper than website prices (insurers want to motivate their clients to use this particular distribution channel).

The decision on a particular insurance arrangement is individual, in general it is possible to arrange premia for the Europe region in the order of tens of CZK as well as in hundreds of CZK, without any relevant extra provided by the more expensive option - described further (more risks covered, higher claim limit, extra services included or any important exclusion).

\section{Main risks covered and coverage limits}

There are two basic approaches for setting up claim limits in the Czech Republic. Usually, there is a limitation in CZK, which is specified for each risk insured. A few insurance companies in the Czech insurance market bring an alternative 
solution without any limit amount for the coverage of medical expenses abroad. Examples of the limits are provided in Table $6 .^{7}$

\section{Tab. 6 Claim limits by risks covered by selected insurance companies $(\text { in } \mathbf{C Z K})^{8}$}

\begin{tabular}{|c|c|c|c|c|c|c|c|c|c|c|}
\hline $\begin{array}{l}\text { Risk } \\
\text { insured }\end{array}$ & AIG & Allianz & $\mathbf{A X A}$ & $\begin{array}{l}\text { Česká } \\
\text { pojišt’o - } \\
\text { vna }\end{array}$ & $\begin{array}{l}\text { ČSOB } \\
\text { pojišsto- } \\
\text { vna }\end{array}$ & $\begin{array}{l}\text { ER- } \\
\text { GO }\end{array}$ & $\begin{array}{l}\text { Gene- } \\
\text { rali }\end{array}$ & $\begin{array}{l}\text { Koo- } \\
\text { pera- } \\
\text { tiva }\end{array}$ & $\begin{array}{l}\text { Uni- } \\
\text { qa }\end{array}$ & $\begin{array}{l}\text { Uni- } \\
\text { on }\end{array}$ \\
\hline $\begin{array}{l}\text { Premium } \\
\text { for covera- } \\
\text { ge }\end{array}$ & 194 & 155 & 67 & 72 & 61 & 60 & 51 & 72 & 56 & 36 \\
\hline $\begin{array}{l}\text { Variant } \\
\text { name }\end{array}$ & $\begin{array}{l}\text { Sil- } \\
\text { ver } \\
\text { Eu- } \\
\text { rope }\end{array}$ & $\begin{array}{r}\text { Opti- } \\
\text { mal }\end{array}$ & $\begin{array}{l}\text { Kom- } \\
\text { fort }\end{array}$ & $\begin{array}{l}\text { Turisti-ka } \\
\text { a poznání }\end{array}$ & A-tlas & $\begin{array}{r}\text { E- } \\
\text { Trip } \\
\text { All }\end{array}$ & $\begin{array}{r}\text { Uni- } \\
\text { versal }\end{array}$ & $\begin{array}{r}\text { Kla- } \\
\text { sik }\end{array}$ & K5 & $\begin{array}{l}\text { Stan- } \\
\text { dard }\end{array}$ \\
\hline $\begin{array}{l}\text { Medical } \\
\text { expenses } \\
\text { main limit }\end{array}$ & $\begin{array}{r}5 \\
\text { mil. }\end{array}$ & Unlim. & 5 mil. & 3 mil. & 3.5 mil. & $\begin{array}{r}5 \\
\text { mil. }\end{array}$ & 3 mil. & 5 mil. & 5 mil. & Unlim. \\
\hline $\begin{array}{l}\text { - Dental } \\
\text { treat-ment }\end{array}$ & $\begin{array}{r}10 \\
\text { ths. }\end{array}$ & 10 ths. & 11 ths. & 3 mil. & 3.5 mil. & 5 ths. & 10 ths. & $\begin{array}{l}10 \\
\text { ths. }\end{array}$ & 5 mil. & 5 ths. \\
\hline $\begin{array}{l}\text { Accident } \\
\text { insurance }\end{array}$ & es & Yes & Yes & Yes & Yes & Yes & Yes & Yes & Yes & Yes \\
\hline - Death & $\begin{array}{l}150 \\
\text { ths. }\end{array}$ & 200 ths. & $\begin{array}{l}250 \\
\text { ths. }\end{array}$ & 100 ths. & 100 ths. & $\begin{array}{l}200 \\
\text { ths. }\end{array}$ & $\begin{array}{l}500 \\
\text { ths. }\end{array}$ & $\begin{array}{l}100 \\
\text { ths. }\end{array}$ & $\begin{array}{l}150 \\
\text { ths. }\end{array}$ & $\begin{array}{l}300 \\
\text { ths. }\end{array}$ \\
\hline $\begin{array}{l}\text { - Perma- } \\
\text { nent } \\
\text { disability }\end{array}$ & $\begin{array}{l}300 \\
\text { ths. }\end{array}$ & 400 ths. & 500 ths. & 200 ths. & 200 ths. & $\begin{array}{l}300 \\
\text { ths. }\end{array}$ & $\begin{array}{l}500 \\
\text { ths. }\end{array}$ & $\begin{array}{l}200 \\
\text { ths. }\end{array}$ & $\begin{array}{l}300 \\
\text { ths. }\end{array}$ & $\begin{array}{l}600 \\
\text { ths. }\end{array}$ \\
\hline $\begin{array}{l}\text { Liability } \\
\text { insurance }\end{array}$ & Yes & Yes & Yes & Yes & Yes & Yes & Yes & Yes & Yes & Yes \\
\hline $\begin{array}{l}\text { - Life } \\
\text { liability }\end{array}$ & $\begin{array}{r}5 \\
\text { mil. }\end{array}$ & 10 mil. & 1 mil. & 2 mil. & 2 mil. & $\begin{array}{r}3 \\
\text { mil. }\end{array}$ & 3 mil. & 4 mil. & 1 mil. & $\begin{array}{r}2.5 \\
\text { mil. }\end{array}$ \\
\hline $\begin{array}{l}\text { - Property } \\
\text { liability }\end{array}$ & $\begin{array}{r}5 \\
\text { mil. }\end{array}$ & 5 mil. & $\begin{array}{l}0.5 \\
\text { mil. }\end{array}$ & $1 \mathrm{mil}$. & 1 mil. & $\begin{array}{r}3 \\
\text { mil. }\end{array}$ & 5 mil. & 4 mil. & 1 mil. & $1 \mathrm{mil}$. \\
\hline $\begin{array}{l}\text { Assistance } \\
\text { services }\end{array}$ & Yes & Yes & Yes & Yes & Yes & Yes & Yes & Yes & Yes & Yes \\
\hline $\begin{array}{l}\text { Luggage } \\
\text { insu-rance }\end{array}$ & $\begin{array}{r}30 \\
\text { ths. }\end{array}$ & 25 ths. & 20 ths. & 10 ths. & 20 ths. & $\begin{array}{r}30 \\
\text { ths. }\end{array}$ & 50 ths. & $\begin{array}{r}30 \\
\text { ths. }\end{array}$ & 15 ths. & \\
\hline
\end{tabular}

Source: Websites of the selected insurance companies.

Table 6 shows selected insurance companies and details of the travel insurance packages that were arranged according to the model example. As there are differences in premiums' amounts, there are also differences in the coverage limits. According to the example, insurance companies that have the largest spread

7 The selection was made mainly based on the participation of individual insurance companies offering the travel insurance on the written premia presented by the Czech Insurance Association in its Annual report 2016.

8 Detail of the example from Table 4 for a person travelling to Europe, data based only on the insurance companies' websites. 
in premia for coverage are AIG (Colonnade) and Union. Union, in this case, offers higher limits for a few risks covered, and except for the luggage insurance, these limits are not less or equal than the minimum limit for each of the risk covered by selected insurance companies in the table. Another reason for premia differences is partially the fact that some products automatically include coverage of specific risks, such as the daily compensation for injury or the coverage of a legal assistance ${ }^{9}$. Another reason is also the client's base excess (participation on claims), too ${ }^{10}$. But in general all the mentioned potential factors for premia differences do not seem to be relevant for the explanation of premia differences in terms of hundreds of per cent and the only missing factor is factoring in different profit margins by individual insurance companies.

It is important to note that this figure is based on the predefined model. Premia vary according to the clients' needs. For example, an update of the main limit for medical expenses by Česká insurance company from CZK 3 million to CZK 100 million costs only CZK 10 in this case. Based on this example, it is difficult to provide the final statement on the limits. Generally speaking ${ }^{11}$, all the limits are sufficient for the coverage of a tourist's trip abroad.

\section{Travel insurance area limits}

Insurance companies usually distinguish among areas of the travellers' final destinations. This approach is not complicated and most insurance companies in the Czech Republic have two or three areas: ${ }^{12}$

- Europe (+ popular destinations such as e.g. Turkey, Tunisia, Egypt, Israel or the Canary Islands) ${ }^{13}$

- rest of the world (excluding selected countries - USA, Canada, Australia, etc.)

- rest of the world (including all + previously deselected countries)

This distinction is caused by higher costs for medical care in selected countries for example in USA, Canada or Australia. An offer of the Ergo insurance company

9 Limit examples: Injury: Allianz CZK 100, Uniqa CZK 300. Legal assistance: AXA CZK 20,000, Allianz CZK 35,000.

10 AXA has a $100 \%$ client base excess for damages of up to CZK 5,000 by liability insurance.

11 Based on the public reports by insurance companies with the maximum of about EUR 50,000 for a heart attack surgery in Turkey. Source: Allianz. 2012. https://www.allianz.cz/vse-oallianz/tiskove-centrum/tiskovy-archiv/rok-2012/Allianz-sestavila-cenovy-zebricek-lekarskychzakroku-v-nejoblibenejsich-destinacich-Cechu--Evropsky--39.html.

12 Sometimes there is only a distinction between Europe and the rest of the world.

13 The European region is a general name - it depends on the given insurance company which countries are included. Europe can be defined, for example, as countries of the European union or according to the geological position or based on the individual insurance company's settings. 
can be used as an example: Europe coverage costs CZK 60, world insurance costs CZK 78 (excl. USA, Canada and Australia) and the whole world costs CZK 138.

Specific situation represent in the case Czech customers clients travelling to Slovakia, especially to its mountain areas. There clients need to arrange the travel insurance that should include the costs associated with the technical part of the intervention of the Mountain Rescue Service.

\section{The purpose of trip limit}

It is important to specify the purpose of a trip and activities because this brings a different premium pricing. There can be also a different process of arrangement: for risky activities, a client has to negotiate the contract directly at the insurance office. It is important to know the basic risks (within the terms and conditions) covered and if necessary, arrange a supplementary insurance for specific - risky activities or specific situations. Most insurance companies understand risk activities as any sport performed on a professional level under championship, race or a competition and also in the role of an arbiter or a sportsperson.

For example let us assume the skiing sport activity. Most of the insurance companies include downhill skiing but sometimes it is important to arrange a supplementary insurance for risky sports. In the case of tourist trips, it would be useful to know that the risk based on a terrorist attack is included. Detail impact of skiing to the amount of a premium and details on the terrorist attack coverage are shown in Table 7 for selected insurance companies.

\section{Tab. 7 Premium with focus of skiing and coverage of terrorist attack $\left(\right.$ in CZK) ${ }^{14}$}

\begin{tabular}{lrrl}
\hline Insurance company & $\begin{array}{l}\text { Standard } \\
\text { price }\end{array}$ & $\begin{array}{l}\text { Skiing } \\
\text { included }\end{array}$ & Terrorists attack \\
\hline Allianz & 190 & 190 & Included (lim. 1.5 mil.) \\
AXA & 67 & 67 & Included (lim. 2.5 mil.) \\
Česká insurance company & 72 & 72 & Included (lim. 3 mil.) \\
ČSOB insurance company & 61 & 61 & Included (lim. 3.5 mil.) \\
Direct & 90 & 90 & Included (lim. 1 mil.) \\
ERGO & 60 & 60 & Included (lim. 5 mil.) \\
Komerční insurance company & 98 & 98 & Included (lim. 3 mil.) \\
Kooperativa & 72 & 108 & Included (lim. 5 mil.) \\
Uniqa & 56 & 70 & Included (lim. 5 mil.) \\
\hline
\end{tabular}

Source: Websites of selected insurance companies.

14 Online based pricing on 30 May 2017 for trip during period 17 June 2017 - 18 June 2017. 
Table 7 shows that it is appropriate to add an extra supplementary insurance for downhill skiing only by Kooperativa and Uniqa. The terrorist attack is included by all the mentioned insurance companies, but the limit for medical expenses varies. Clients need to understand that risks covered by the arranged travel insurance will be claimed by the insurance company only for risks included in the contract (Rejda, McNamara, 2014).

\section{Current health condition and age as a factor for the price differences}

Travel insurance mainly focuses on the coverage of medical expenses abroad. These expenses can be higher and the travel insurance arrangement may be quite complicated for clients who already had health complications prior to the trip (Hardham, 2010). Due to this, it is necessary that the prospective client is in a good health condition. This argument is supported by the definition that is included into the exclusion part of terms and conditions by most of the insurance companies: The insurer will not pay for a claim by acute illness that existed prior to travel to the insured route or chronic illness of the insured or their complications.

Travel insurance is a product for people of different age. Currently, anyone is able to take out the travel insurance but there can be quite substantial differences in the premium pricing. The insurance premium is mostly divided into groups according to age. Generally, there can be distinguished children and adolescents, adults and seniors. This fact demonstrates an example in Table 8, which analyses one day insurance for people of different age by the Uniqa insurance company.

Tab. 8 Standard / Online premium for travel insurance according to age (price per day, in CZK)

\begin{tabular}{lll}
\hline Age & Austria & World \\
\hline $0-65$ & $31 / 28$ & $54 / 49$ \\
$66-80$ & $54 / 49$ & $108 / 97$ \\
81 and more & $81 / 73$ & $162 / 146$ \\
\hline
\end{tabular}

Source: www.uniqa.cz, as of 23 May 2017.

Note: Standard premium / online premium.

Table 8 shows that Uniqa differentiates three age groups and insurance of the most risky group for 81 years old people is approximately three times more expensive than premia for "standard aged" people. This is consistent with the statement that there is a higher probability of realization of any risk and payment of indemnity by older people.

Another example can be AIG: elderly people (69 - 78 years of age) are quite limited in arranging insurance as insurance companies have an age limit for insurance; for example, AIG limits the age to 78 years. 


\section{Length of the trip limit}

Commercial travel insurance is arranged on time-limit basis. Usually the travel insurance can be arranged for:

- short-term trips: Travel insurance is arranged for the period of a specific number of days, usually maximum of about $7-30$ days. According to the terms and conditions, the maximum period is about 60 or 120 days for this type of product. A typical client is an individual with a short-term holiday-like stay by the sea, stay in the mountains or tours.

- repeated trips: Travel insurance is arranged for a specific interval of days. The client can travel abroad several times and it is not necessary to arrange a new insurance each time the client wants to go abroad during the specified interval. Important limit for this type of insurance is that the return from each trip has to be realized within the specified period - for example 45 days. The typical client will be an employee, who is travelling abroad frequently.

- long-term stays: This type of the travel insurance is arranged for one year at maximum. There is a possible renewal and premia range according to the associated risk factors in the order of thousands of CZK. The typical customer will be a company traveller or discoverer.

\section{Exclusions in the travel insurance}

In general, it is important that there are no suspicions for the claim prior to the insurance period and in the case of realization of risks; this has to be sudden and not intentional. In more detail, there is a list of selected exclusions. The insurance company will not pay for a claim in the case when ${ }^{15}$ :

- the damage occurred in connection with ingestion of an alcohol or addictive substances

- the damage occurred in connection with the suicide attempt

- the damage occurred to the client without usage of the necessary equipment

- the damage occurred following a disobey of instruction given by the staff

- the damage occurred under extreme conditions - for example, altitude over $3,000 \mathrm{~m}$

- the damage occurred in specific areas restricted by any authority

- the damage occurred by the professional activity - sport activity

15 List of selected and important exclusions; Terms and conditions for the travel insurance of insurance companies. For the concrete insurance it is important to understand exclusions of the concrete insurance company. 
Rybák, Z.: Analysis of the Individual Travel Insurance in the Czech Republic.

- the damage occurred under consequences of chronical disease that manifested over the past twelve months

Due to the notable price difference between AIG and Union, the general terms and conditions were also compared. Neither there was found any notable difference among exclusions.

Travel insurance after five months' shift

One part of the analysis of the travel insurance market was to provide an overview of the change in the travel insurance products and/or in their pricing within a five months' time shift ${ }^{16}$ Details of premia after the time shift analysis are shown in Table 9.

Tab. 9 Premia for the example coverage (as of October 2017, in CZK)

\begin{tabular}{|c|c|c|c|c|c|}
\hline \multirow[b]{2}{*}{$\begin{array}{l}\text { Insurance } \\
\text { company }\end{array}$} & \multirow{2}{*}{$\begin{array}{l}\text { Main limit } \\
\text { for } \\
\text { medical } \\
\text { expenses } \\
\text { coverage }\end{array}$} & \multicolumn{2}{|c|}{ Austria } & \multicolumn{2}{|c|}{ USA / world } \\
\hline & & $\begin{array}{l}\text { www.top- } \\
\text { pojisteni.cz }\end{array}$ & Other channels & $\begin{array}{l}\text { www.top- } \\
\text { pojisteni.cz }\end{array}$ & $\begin{array}{l}\text { Other } \\
\text { channels }\end{array}$ \\
\hline AIG/Colonnade & 5 mil. & 194 & $\begin{array}{l}\text { website: } 149> \\
267\end{array}$ & 495 & $\begin{array}{l}\text { website: } 495> \\
680\end{array}$ \\
\hline Allianz & unlimited & 190 & website: 194 & 630 & website: 630 \\
\hline AXA & 5 mil. & 40 & website: 84 / 67 & $63>126$ & $\begin{array}{l}\text { website: } 128 \text { / } \\
102\end{array}$ \\
\hline $\begin{array}{l}\text { Česká } \\
\text { insurance } \\
\text { company }\end{array}$ & 3 mil. & - & $\begin{array}{l}\text { website: } 80 \text { / } 72 \text {; } \\
\text { android app: } 72\end{array}$ & & $\begin{array}{l}\text { website: } 124 \text { / } \\
\text { 111; android } \\
\text { app: } 111\end{array}$ \\
\hline С̆PP & $2,500,000$ & - & website: 63 / 50 & - & $\begin{array}{l}\text { USA } \\
\text { impossible }\end{array}$ \\
\hline $\begin{array}{l}\text { ČSOB } \\
\text { insurance } \\
\text { company }\end{array}$ & 5 mil. & 42 & website: $61>67$ & $70>0$ & $\begin{array}{l}\text { website: } 103> \\
115\end{array}$ \\
\hline Direct & unlimited & - & website: $90>98$ & - & $\begin{array}{l}\text { website: } 135> \\
148\end{array}$ \\
\hline ERGO & 5 mil. & 54 & website: 60 & 124 & website: 138 \\
\hline ERV & 3 mil. & 190 & website: 250 & 690 & website: 370 \\
\hline Generali & 3 mil. & 44 & website: 51 & 70 & website: 77 \\
\hline HVP & 3 mil. & - & - > website: 63 & - & $\begin{array}{l}->\text { website: } \\
103\end{array}$ \\
\hline $\begin{array}{l}\text { Komerční } \\
\text { insurance }\end{array}$ & 3 mil. & - & $\begin{array}{l}\text { website } 108 \text { / } \\
\text { 98; android app: }\end{array}$ & - & $\begin{array}{l}\text { website } 108 \text { / } \\
98>90 / 81\end{array}$ \\
\hline
\end{tabular}

16 Source: Own table based on the data collected online (23 October 2017 - 24 October 2017). 


\begin{tabular}{|c|c|c|c|c|c|}
\hline \multirow{2}{*}{$\begin{array}{l}\text { Insurance } \\
\text { company }\end{array}$} & \multirow{2}{*}{$\begin{array}{l}\text { Main limit } \\
\text { for } \\
\text { medical } \\
\text { expenses } \\
\text { coverage }\end{array}$} & \multicolumn{2}{|c|}{ Austria } & \multicolumn{2}{|c|}{ USA / world } \\
\hline & & $\begin{array}{l}\text { www.top- } \\
\text { pojisteni.cz }\end{array}$ & Other channels & $\begin{array}{l}\text { www.top- } \\
\text { pojisteni.cz }\end{array}$ & $\begin{array}{l}\text { Other } \\
\text { channels }\end{array}$ \\
\hline company & & & $62 / 56$ & & $\begin{array}{l}\text { android app: } \\
100 / 90>90 / \\
81\end{array}$ \\
\hline Kooperativa & 5 mil. & - & website: 80 / 72 & - & $\begin{array}{l}\text { website: } 112 / \\
101\end{array}$ \\
\hline Maxima / Bupa & - & - & - & - & - \\
\hline Slavia & 3.5 mil. & 46 & $\begin{array}{l}\text { website: } 50 \\
\text { (coverage } 5000 \\
000)\end{array}$ & $74>84$ & $\begin{array}{l}\text { website: } 108 \\
\text { (coverage } \\
5000000)> \\
70\end{array}$ \\
\hline Uniqa & 5 mil. & 52 & $\begin{array}{l}\text { website: } 62 \text { /56 } \\
>54 / 49\end{array}$ & 98 & $\begin{array}{l}\text { website: } 108 \text { / } \\
97\end{array}$ \\
\hline Union & 2.5 mil. & 68 & $\begin{array}{l}\text { website: } 36 \\
\text { (unlimited } \\
\text { coverage) }\end{array}$ & 92 & $\begin{array}{l}\text { website: } 80 \\
\text { (unlimited } \\
\text { coverage) }\end{array}$ \\
\hline Vitalitas & 5 mil. & - & website: 74 & - & website: 162 \\
\hline VZP & 2 mil. & 40 & $\begin{array}{l}\text { website: } 36 \\
\text { (coverage } 3 \\
\text { mil.) > } 63\end{array}$ & 64 & $\begin{array}{l}\text { website: } 103 \\
\text { (coverage } \\
3 \text { mil.) }\end{array}$ \\
\hline
\end{tabular}

Source: Websites of selected insurance companies.

Note: ">" means an update in price.

There are few changes shown in the above table. The most notable increase (100\% and more) is in the premium of AXA by the Top-pojisteni intermediary (which was an alignment to its own website pricing). An update by AIG was very important and becomes the most expensive premium for the coverage. AIG premium is in comparison approximately seven times higher than in the case of the Union insurance company. Other premia updates slightly increased or decreased.

The main findings following the five months' time shift are within the ERV, Evropská insurance company. The insurance company added a new element for the travel insurance products - insurance participation (excess) to its insurance products amounting to CZK 1,500 for each insurance claim. There is also an option to insure this participation for CZK 40 for the period of two days.

Another finding was that HVP insurance company started to insure via their own website, which did not work in May 2017. The appearance of website used for the sale of HVP travel insurance products was same as by the VZP and Slavia insurance company. There can possibly be a co-operation among insurance 
Rybák, Z.: Analysis of the Individual Travel Insurance in the Czech Republic.

companies on the travel insurance products. This can be supported by the fact that HVP has the same prices as VZP.

\section{Central European comparison}

The travel insurance is a worldwide-adopted insurance product. An analysis of the travel insurance in the Central European region was conducted for Germany, Austria, Slovakia, Poland and Hungary. It has been analysed through arranging the travel insurance for individuals (see the definition of an individual at the beginning of Chapter 4), insurance period 16 February 2018 - 17 February 2018, destination Europe and an assumption of the lowest premium for the medical and liability insurance. According to this specification, there was performed a comparison of the premium and basic (the highest available) claim limit, including the medical expenses coverage, defined by the insurance company. This part abstracts away from analysing the terms and conditions. For a better comparison, there are selected insurance companies represented by international insurance groups which operate within the region. Results of the comparison are shown in Table 10 and Table 11.

\section{Tab. 10 Premium for the basic travel insurance coverage across selected countries by selected insurance companies (in CZK)}

\begin{tabular}{lrrrrrr}
\hline $\begin{array}{l}\text { Insurance } \\
\text { company }\end{array}$ & $\begin{array}{l}\text { Czech } \\
\text { Republic }\end{array}$ & Poland & Germany & Hungary & Slovakia & Austria \\
\hline Allianz & 194 & 78 & $302(\mathrm{~A})$ & 90 & 116 & $4,506(\mathrm{~A})$ \\
Generali & 51 & 92 & - & - & 91 & - \\
AXA & 67 & 71 & $201(\mathrm{~A})$ & - & 82 & 147 \\
ERV & 170 & 95 & $279(\mathrm{~A}-$ & 41 & 175 & 660 \\
VIG & 72 & - & $-243)$ & 111 & 67 & 609 \\
Colonnade & 94 & 115 & - & 63 & - & - \\
$\begin{array}{l}\text { Average across } \\
\text { countries }\end{array}$ & 108 & 90 & 279 & 76 & 106 & 484 \\
\hline
\end{tabular}

Source: Websites of selected insurance companies. Exchange rate ČNB as of 15 February 2018.

Note: (A) - annual premium.

Table 10 shows the premium of basic travel insurance coverage in the region (limits for medical expenses are in Table 11 and liability insurance is included). Premia and approaches to premia pricing differ among countries. The most different approach for the premium pricing is in Germany, where there is commonly adopted an annual premium (i.e. it is impossible to arrange a one-trip insurance) pricing for the coverage - annual premium in Germany is disproportionate to insurance companies in other countries, which offer only two 
days coverage. Another annual premium approach has been found by Allianz in Austria with a higher price for coverage than usual. The premium for a one-trip coverage is the most expensive in Austria. It is more expensive than in the Czech Republic. The cost of a one-trip premium is approximately same across the Czech Republic, Poland and Hungary.

Across the region, there are quite substantial differences (in hundreds of per cent) in the premiums (e.g. ERV in the Czech Republic and in Austria). Provided all the products are suitable for the travel insurance coverage, it could be interesting to analyse the depth of risk coverage (claim limits) as the potential source of differences in the premiums. Table 11 shows the travel insurance basic claim limits for medical care.

\section{Tab. 11 Claim limits for medical expenses by selected insurance companies (in CZK)}

\begin{tabular}{lrrrrrr}
\hline $\begin{array}{l}\text { Insurance } \\
\text { company }\end{array}$ & $\begin{array}{l}\text { Czech } \\
\text { Republic }\end{array}$ & \multicolumn{1}{c}{ Poland } & Germany & Hungary & Slovakia & Austria \\
\hline Allianz & Unlimited & $1,221,800$ & Unlimited & $5,291,000$ & Unlimited & $8,118,400$ \\
Generali & 3 mil. & $1,221,800$ & - & $2,442,000$ & $5,074,000$ & Unlimited \\
AXA & 5 mil. & $2,537,000$ & Unlimited & - & $5,074,000$ & $5,074,000$ \\
ERV & 3 mil. & $1,014,800$ & Unlimited & $2,442,000$ & $5,581,400$ & Unlimited \\
VIG & 5 mil. & - & - & $1,628,000$ & $2,537,000$ & Unlimited \\
Colonnade & 5 mil. & $1,268,500$ & - & $1,628,000$ & - & - \\
\hline
\end{tabular}

Source: Websites of selected insurance companies. Exchange rate ČNB as of 15 February 2018.

Table 11 describes differences in claim limits for the basic coverage of medical expenses offered by insurance companies. In Germany and Austria, the claim amounts are higher or outright unlimited, which fact is reflected in the higher premia. In the case of Germany, prices are mostly stated for the annual coverage, which is advantageous. This differs from the Czech Republic and Slovakia. This is represented by the claim amounts of about CZK 5 million (except for Allianz, which offers an unlimited coverage). Opposite to the limits in Germany and Austria are limitations in Poland and Hungary. Over there, the basic travel insurance products start with extremely low limits and based on experiences of the Czech market, the amounts offered may not be sufficient for covering the potential risks abroad.

Generally it is possible to state that premia amounts correspond with the lower claim limits but there are substantial differences among countries. It is much cheaper and comfortable to arrange annual travel insurance in Germany for roughly CZK 300 (EUR 11.9) with an unlimited claim limit for covering medical expenses than in Poland, where the two days' protection costs CZK 78 (PLN 
12.76) with a limit of only CZK $1,221,800$ (PLN 200,000). It is interesting that both products - German unlimited and Poland limited are offered by Allianz insurance company. There is not similar approach by travel insurance products in the central Europe region through one insurance group. In Austria, premia are the most expensive, although there is not any relevant advantage in claim limits compared to the same products in Germany or the Czech Republic.

According to online premium calculations, websites and documents analyses, there are couple of differences in the travel insurance products across the countries. Products in Germany are focused on an unlimited coverage; usually there is an offer for an annual coverage for a cheap premium. As a striking example we may mention Allianz insurance company and its unlimited coverage of medical expenses for EUR 11.90. There were found other pricing factors that could potentially affect the premia, e.g. the means of transport by German insurance companies. Travelling by boat is understood as more risky and therefore more expensive, so in this case an annual coverage is offered (not supplementing the one-trip insurance but replacing it instead, Austria insurance offers solely this type of the travel insurance). Great importance on extra insurance of travel expenses is put in Austria, where it is separately offered by online premium calculations. It is also interesting to note that there was introduced a reduction of the unlimited claim amount to $90 \%$ for people who do not have a social insurance. In the case of Poland it is important to express the current state of people insured - there are questions about chronical diseases by arrangement. Hungarian travel insurance is the cheapest but it provides an extremely low protection for potential high costs of medical care abroad, which may not be identified by clients with low financial literacy. In Slovakia, the approach of travel insurance companies, premia and limits are similar to the Czech Republic.

\section{Discussion}

The travel insurance market in the Czech Republic is competitive and there is a sufficient supply of travel insurance products. Travel insurance is offered by a number of insurance companies and there is a large variety among product packages, including risk insured and different claim limits. There are numerous factors (claim limits used in the final offer, all risks included, details in the terms and conditions, tourist trip destination, purpose of the trip, age and health condition) that influence the final premium. Nevertheless, based on the model example these factors do not reflect the observed differences in terms of hundreds of per cent of premiums. According to the model comparison of travel insurance products which provides in a selected few cases the same coverage for a different price, it is possible to state that the profit margin is one of the most important factors behind the premia differences. 
The cheapest insurance (insurance for individuals, as oppose to the associated insurance by debit/credit cards) options are sufficient for covering the potential costs of medical care abroad vis-a-vis the claims reported by insurance companies. Sufficiency of the claim amounts reported in the analysis is also due to the fact that insurers are highly motivated for the maximally speedy transport (repatriation) to the Czech Republic. Finally, it is possible to save money by shopping around, since the coverage with equal limits vary in its pricing among individual insurance companies. There is a large scale of discounts, too, e.g. for students, loyal customers, specific groups, etc.

It is important to understand the risks covered. For example, in case the client goes skiing, s/he has to know if this sport is included in the insurance coverage. In the case of travelling to the mountains, it is important to be sure about the height above the sea level reached, because insurance companies set the limits, e.g. at an altitude of 3,000 m. Another important aspect is to understand one's own health condition. There exist exclusions for chronical diseases such as diabetes. In this case, it is important to stabilise the state of health twelve months prior to a shortterm trip. The person needs to be checked whether he or she is insurable due to one's age. Otherwise, the client needs to check its insurability by the insurance company or it has to arrange a supplementary insurance. The travel insurance also applies for foreigners when traveling to their country of origin. The insured needs to understand the part of terms and conditions related to exclusions. This explains situations when the insurance company will not cover the potential claim. For example: a claim needs to take place unintentionally, the claim must not be influenced by alcohol or drugs and it must not arise in relation to a criminal activity.

The main distribution channel is through intermediaries - travel agents. The travel insurance is an insurance product which is easily arranged through modern electronic distribution channels. Use of electronic distribution channels generally offers the cheapest and most comfortable option for an arrangement of insurance in cases when the travel insurance is not included (for example within the price of a tourist trip). It is necessary for the client to gain basic financial literacy and to arrange the insurance according to his or her needs.

There are fewer companies providing assistance services than insurance companies. Insurance companies mainly set claim limits and risks insured. During a claim, there occurs a co-operation with a company providing assistance services. Assistance services do not enter into play only once the claim happens. These services can be used prior to the trip for getting important information (e.g. on the current situation, weather, etc.). Assistance services are provided in a wide choice of language. 
The travel insurance market is profitable and due to a relatively low claim ratio, there could appear a trend of new insurance companies entering the market. Insurers will probably increase the claim limits to an unlimited level of the medical expenses coverage, which could be the potential base for increasing the premia. This is just a marketing plot of travel insurance companies, as the cost for claims is maximally in the order of CZK millions as oppose to tens of millions per claim. There is a new approach for pricing in that insurance has an excess, when the client needs to pay a contribution of CZK 1,500 per insurance event. ${ }^{17}$ This could be adopted by other insurance companies as a motivation for clients to report only more expensive claims. There is a trend of premia differentiation based on the new factors - means of transport, age group, final destination or more detailed description of the current health condition of the respective policyholder. So the insurers will have to find a balance among an attractive product, simple product and insurance risk pricing. Insurers will continue with dissemination of risks covered or services included (household insurance, assistance services, insurance for a rented car, etc.). It is also possible that a few companies will offer travel insurance on annual basis as oppose to the daily basis. Insurers will potentially expand the distribution of travel insurance products through new electronic distribution channels, such as selling via Facebook messenger, specific applications or through a bank - insurance products.

\section{Conclusion}

This paper focuses in detail on a specific product of the Czech insurance market short-term individual travel insurance. It provides the analysis of the travel insurance in the Czech Republic with a detailed focus on prices, premia prices, risks covered, claim limits, product distribution and terms and conditions.

The travel insurance market in the Czech Republic is a developed and competitive one. There are approximately twenty insurance companies providing coverage of risks that can be included under an individual travel insurance product package (including insurance of medical expenses abroad, liability insurance, etc.). The travel insurance is quite a profitable product because claim ratios are slightly above $30 \%$ (which is below the average for the whole market and also below the solely non-life insurance market's average). Due to this fact, it is possible to argue that there is still a scope for new insurance companies entering the market.

Based on the analysis, there is a large variety of product packages offered in the Czech Republic. According to the model example, travel insurance with minimal

17 Source: ERV insurance company, www.erv.cz, 31 October 2017. It is possible to reduce this excess with an extra payment of about CZK 40 per day and less for a prolonged holiday stay. 
limits offered in the Czech Republic provides sufficient coverage in the case of an unexpected medical treatment. Generally speaking it is possible to say that all the analysed travel insurance products are suitable for travelling abroad. The main finding of the analysis with a focus on the pricing is that prices in the Czech Republic for the coverage vary. There are differences in hundreds of per cent for approximately the same coverage. The reason of price differences are based partially on the insurance risk factors, such as claim limits used in the final offer, all risks included, details in the terms and conditions, tourist trip destinations, purposes of the trip, age and health condition. Nevertheless, since according to the model example there are differences in hundreds of per cent in premiums, it is possible to conclude that an important price factor is the profit margin. The main source of clients' discounts on insurance premia is the use of modern electronic distribution channels, which reduce additional costs to insurers for insurance intermediaries. There is also a new approach of insurance companies in using the client excess per insurance claim - about CZK 1,500 per claim. Travel insurance companies offer sufficiently stable pricing in time. Travel insurance is the most favourite product sold through electronic distribution channels while currently the most used is the traditional distribution channel through intermediaries (tour operators).

Travel insurance in the Czech Republic provides a sufficient coverage for optimal price in comparison with the Central European region. Premiums for coverage in the Czech Republic are comparable to other countries within the region (though in Germany the prices are lower as there is usually adopted the travel insurance with annual premium pricing - after re-calculating into daily basis). According to the model example, the claim limits are more comparable to the higher limit levels in Germany, Austria and Slovakia than to the lower limits in Poland or Hungary.

Based on the comparison within the region and the current travel insurance setting of the Czech Republic, it is possible to express potential trends within the travel insurance products. Insurers will increase claim limits by risks insured to the unlimited restriction (attractive for product marketing) and as a result, the associated premia will potentially increase. Insurers will potentially differentiate premia according to the new factors such as the means of transport, detail health condition - the travel insurance product will be more individual while preserving simplicity. Premia will possibly contain some kind of participation in order to exclude small claims (excess). Insurers will offer coverage of new risks and/or services included in the basic travel insurance package (household insurance, insurance of a rented car). Travel insurance will be offered through new, especially electronic distribution channels, or included directly in the price of a product or a service (payment card, tour). 
Rybák, Z.: Analysis of the Individual Travel Insurance in the Czech Republic.

Travel insurance is a very important insurance product, protecting clients against extreme costs abroad. It is an easily arranged product. It is important to understand the product's details (risks covered and claim limits covered) which should be set up according to the client's needs and travelling purpose. As it is the most common product of insurance, the client should fully understand the terms and conditions, itself not always an easy task, or at least focus on the exclusions.

\section{References}

AIG, 2017. Available from: <www.aig.cz>. [30 May 2017].

Colonnade, 2018. Available from: 〈www.colonnade.cz〉. [30 May 2017].

Allianz insurance company, 2017. Available from: 〈www.allianz.cz〉. [30 May 2017].

Allianz, 2012. Allianz sestavila cenový žebříček lékařských zákroků v nejoblíbenějších destinacích Čechů. Evropský průkaz. Available from: $<$ https://www.allianz.cz/vse-o-allianz/tiskove-centrum/tiskovy-archiv/rok2012/Allianz-sestavila-cenovy-zebricek-lekarskych-zakroku-v-nejoblibenejsichdestinacich-Cechu--Evropsky--39.html>. [13 May 2017].

Allianz, 2014. Cena za ošetření v cizině podle Allianz stále roste. Draho vás může přijít i obyčejná škytavka. Available from: <https://www.allianz.cz/vse-oallianz/tiskove-centrum/tiskovy-archiv/rok-2014/cena-za-osetreni-v-cizine-podleallianz.html>. [14 May 2017].

Andreeva, T., 2016. Travel Insurance Cover. Economic Alternatives 1, 93-109. Available from: <https://www.unwe.bg/uploads/Alternatives/Andreeva_br1_ 2016-9.pdf>. [12 June 2017].

AXA insurance company, 2017. Available from: 〈www.axa.cz〉. [30 May 2017]. Česká insunarnce company, 2017. Available from: <www.ceskapojistovna.cz>. [30 May 2017].

Česká podnikatelská insurance company, 2017. Available from: 〈www.cpp.cz〉. [30 May 2017].

Česká spořitelna, 2017. Available from: <www.csas.cz>. [30 May 2017].

Cipra, T., 2006. Insurance mathematics - Theory and practice. Ekopress, Prague.

ČSOB insurance company, 2017. Available from: <www.csobpoj.cz>. [30 May 2017].

ČSOB, 2017. Available from: <www.csob.cz>. [13 July 2017].

Czech Insurance Association, 2017. Available from: 〈www.cap.cz〉. [18 July 2017]. 
Czech National Bank, 2017. Regulated institutions and registered financial market entities lists. Available from: <https://apl.cnb.cz/apljerrsdad/JERRS.WEB07.INT RO_PAGE?p_lang=en>. [23 May 2017].

Direct insurance company, 2017. Available from: 〈www.direct.cz〉. [30 May 2017].

Ducháčková, E., 2009. Principles of insurance. Ekopress, Prague.

Ducháčková, E., Daňhel, J., 2012. Insurance markets: changes in insurance industry v global era. Professional Publishing, Prague.

Ergo insurance company, 2017. Available from: <www.ergo.cz〉. [30 May 2017].

ERV insurance company, 2017. Available from: 〈www.ervpojistovna.cz〉. [30 May 2017].

Fio bank, 2017. Available from: <www.fio.cz〉. [12 July 2017].

Generali insurance company, 2017. Available from: 〈www.generali.cz〉. [30 May 2017].

Hardham, P., 2017. Pre-Existing Conditions - Could They Invalidate Your Travel Insurance? Journal - Australian and New Zealand Institute of Insurance and Finance 33, 24.

Hasičská vzájemná insurance company, 2017. Available from: <www.hvp.cz〉. [30 May 2017].

Hun Seog, S., 2010. The economics of risk and insurance. Chichester, WileyBlackwell.

ISIC, 2017. Available from: <www.isic.cz/pojisteni/>. [13 July 2017].

Komerční banka, 2017. Available from: 〈www.kb.cz〉. [12 July 2017].

Komerční insurance company, 2017. Available from: <www.komercnipojistovna.cz>. [30 May 2017].

Kooperativa insurance company, 2017. Available from: 〈www.kooperativa.cz〉. [30 May 2017].

Maxima insurance company, 2017. Available from: <www.maximapojistovna.cz>. [30 May 2017].

MBANK, 2017. Available from: <www.mbank.cz〉. [12 July 2017].

Ministry of Health of the Czech Republic, 2016. Available from: <http://www.mzcr.cz/dokumenty/zmeny-poctu-pojistencu-jednotlivychzdravotnich-pojistoven-mezi-112010-a-1_6183_114_1.html>. [31 October 2017].

Rejda, E. G., McNamara, J. M., 2014. Principles of risk management and insurance. Global edition. Pearson Education, Harlow. 
Rybák, Z.: Analysis of the Individual Travel Insurance in the Czech Republic.

Sharkey, B., 2017. Travel Health Insurance: The Unexpected New Necessity. California Broker 35, 10-12.

Slavia insurance company, 2017. Tušíte, kolik zaplatíte za ošetření zlomeniny při lyžování v Alpách? Available from: <http://www.slavia-pojistovna.cz/cs/novinky/ tusite-kolik-zaplatite-za-osetreni-zlomeniny-pri-lyzovani-v-alpach-67>. [16 June 2017].

Slavia insurance company. 2017. Available from: <www.slaviapojistovna.cz>. [30 May 2017].

Top-Pojištění.cz s.r.o., 2017. Available from: <www.top-pojisteni.cz>. [30 May 2017].

Union insurance company, 2017. Available from: <www.unionpojistovna.cz>. [30 May 2017].

Uniqa insurance company, 2017. Available from: 〈www.uniqa.cz>. [30 May 2017].

Vitalitas insurance company, 2017. Available from: 〈www.vitalitas.cz〉. [30 May 2017].

VZP insurance company, 2017. Available from: <www.pvzp.cz>. [30 May 2017]. 